\title{
Information Technology in Dentistry
}

Rajiv Saini*

Department of Periodontology and Oral Implantology, Pravara Institute of Medical Sciences-Loni, Maharashtra, India

*Corresponding author: Rajiv Saini, Associate Professor, Department of Periodontology and Oral Implantology, Pravara Institute of Medical Sciences-Loni, Maharashtra, India, Tel: +02422273600; E-mail: drperiodontist@yahoo.co.in

Received Date: Aug 01, 2016; Accepted Date: Aug 02, 2016; Published Date: Aug 10, 2016

Copyright: (c) 2016 Saini R. This is an open-access article distributed under the terms of the Creative Commons Attribution License, which permits unrestricted use, distribution, and reproduction in any medium, provided the original author and source are credited.

\section{Information Technology}

The rapid expansion and exposure of information technology has affected modern life across a broad spectrum. Health and medical sector also get gear up with advances in modern technology and application of computers. Despite the significant conceptual breakthroughs of the 1960s, all medical informatics, including dental, have faced major impediments in the shape of systems performance and integration issues [1].

Dental informatics is the application of computer and information science to improve dental practice, research, education, and management. A relatively new field, dental informatics can provide significant support to clinical care.

Dental informatics is more than just the application of computing to dentistry. The earliest dental informatics pioneers described their approach as the application of information science to solving medical problems [2].

With the overwhelming rapid development of computer and Information Technology (IT) in the past decade, modern dental research was becoming more dependent on informatics. However, it is important to distinguish informatics from IT. Informatics focuses on research and evaluation of computing applications, information models, and occasionally looks into how to set up, organize, and process digitization based on existed hardware and software. By contrast, IT primarily focuses on the development and implementation of computer technology and telecommunication [3].

Dental informatics combines dentistry and several disciplines, such as computer science and telecommunications. Limited areas of overlap exist between information technology and dental informatics. The main goal of dental informatics is to improve patient outcomes. A secondary goal is to make the delivery of dental care more efficient, for example, by maintaining or improving cost-benefit ratios.

Dental informatics has many applications in dentistry and dental hygiene, including dental education, record keeping, Computer-Aided Design/Computer-Aided Manufacturing (CAD/CAM), computer video imaging, digital radiography, teledentistry, and research. Each component application is highlighted under Table 1.

Dental Informatics has the potential to improve the efficacy, organization, and overall quality of oral care provided by dental professionals. Dental professionals can integrate information technology into practice by seeking out information about dental technology. The field of dental informatics is continually evolving and expanding since its creation. The newer technology will add more value additions by converting technology into modern clinical practice, education and research.

\begin{tabular}{|c|c|c|}
\hline Sr. No. & Unique Features & Application \\
\hline 1 & Education & $\begin{array}{ll}\text { - } & \text { Computed assisted learning tools } \\
\text { - } & \text { E-text books/journals } \\
\text { - } & \text { Simulation Clinics } \\
\text { - } & \text { Seminars and Presentation } \\
\text { - } & \text { Broadcasting teaching and Webinars }\end{array}$ \\
\hline 2 & Electronic Records & $\begin{array}{ll}\text { - } & \text { Electronic Insurance Claim } \\
\text { - } & \text { E-prescription } \\
\text { - } & \text { Patient Clinical and Compliance Records } \\
\text { - } & \text { Patient Care database } \\
\text { - } & \text { Central Diagnostic Unit } \\
\text { - } & \text { Medical Alerts, Expert opinion } \\
\text { - } & \text { Interdisciplinary Collaboration }\end{array}$ \\
\hline 3 & $\begin{array}{ll}\text { Design } & \text { and } \\
\text { Production } & \end{array}$ & $\begin{array}{ll}\text { - } & \text { Computer-Aided Design (CAD) } \\
\text { - } & \text { Computer-Aided Manufacturing (CAM) } \\
\text { - } & \text { Dental materials, impression techniques } \\
& \text { and pre-fabricated appliances } \\
\text { - } & \text { Implant System } \\
\text { - } & \text { 3D Models }\end{array}$ \\
\hline 4 & Teledentistry & $\begin{array}{ll}\text { - } & \text { Extension of education beyond } \\
\text { - } & \text { geographical reach } \\
\text { - } & \text { Cost-effective } \\
\text { - } & \text { Public awareness campaign }\end{array}$ \\
\hline 5 & Research & $\begin{array}{ll}\text { - } & \text { E-Record for universal access } \\
\text { - } & \text { Standardization of Data Analysis } \\
\text { - } & \text { Data Monitoring and Management } \\
\text { - } & \text { Rapid processing time } \\
\text { - } & \text { Data Collection specially } \\
& \text { epidemiological and genetic studies }\end{array}$ \\
\hline 6 & Patient Education & $\begin{array}{ll}\text { - } & \text { Diagnostic Education } \\
\text { - } & \text { Virtual Treatment Display } \\
\text { - } & \text { Compliance and Follow Up track } \\
\text { - } & \text { Emergency Alerts } \\
\text { - } & \text { Patient Motivation and Consent } \\
\text { - } & \text { Chair-side Computing and Analysis }\end{array}$ \\
\hline 7 & Digital radiography & $\begin{array}{ll}\text { - } & \text { Computer-aided image interpretation } \\
\text { - } & \text { Image enhancement } \\
\text { - } & \text { Reduction of radiation exposure } \\
\text { - } & \text { Image Retrieval }\end{array}$ \\
\hline
\end{tabular}

Table 1: Dental Informatics Application in Dentistry

The table above gives the information of different applications of Dental Informatics with different unique features. 
Citation: Saini R (2016) Information Technology in Dentistry. Dentistry 6: e120. doi:10.4172/2161-1122.1000e120

Page 2 of 2

\section{References}

1. Reynolds PA, Harper J, Dunne S (2008) Better informed in clinical practice - a brief overview of dental informatics. Br Dent J 204: 313-317.

2. Ledley RS, Lusted LB (1959) Reasoning foundations of medical diagnosis. Science 130: 9-21.
3. Qi S, Yan Y, Luo E, Hu J (2015) The development of dental informatics and dental information technology in China: A systematic study. J Dent Sci 10: 176-184. 